squealed, struggled and bit harmlessly with its needle-sharp teeth. Between attempts to escape it energetically licked its wings, prompted possibly by emotional stress.-E. G. M. GooDWIN (Lieut.-Col.).

\title{
Badgers and Foxes eating Whortleberries
}

In Switzerland and presumably in other wine-growing countries, it is a recognized fact that badgers and foxes eat numbers of grapes. So do dogs and mainly for this reason shooting in vineyards is not permitted until the grapes have been picked. In Switzerland and in the part of France adjoining it, both foxes and badgers are considered good to eat. A Swiss chasseur told me that he preferred fox cub to hare, but turned up his nose at an old dog fox.-Anthony Buxton.

\section{NOTICE}

\section{APRIL CONFERENCE ON BRITISH MAMMALS}

It is announced that a three-day conference on British mammals will take place at the University of Birmingham's Centre for Continued Studies, Selly Oak, Birmingham, at the week-end after Easter, from Friday evening, 23rd April, to Monday morning, 26th April. During the conference it is proposed to launch a national society for the study of British mammals, with the object of collecting and collating local records of mammals, of promoting field research in mammals, and generally performing for mammals many of the functions performed for birds by the British Trust for Ornithology.

The suggestion originated from Mr. G. B. Hindle, Biology Master of Kings Norton Grammar School, Birmingham, and an informal meeting was held at the offices of the Zoological Society of London in September, 1953, to discuss it. This meeting was attended by G. B. Hindle, Oliver Hook, L. Harrison Matthews, T. C. S. Morrison-Scott, T. J. Pickvance, H. N. Southern, Sir William Taylor and H. V. Thompson. As a result a subcommittee consisting of Messrs. Hindle, Pickvance and Southern was appointed to make arrangements for the conference.

Particulars of the conference may be had from T. J. Pickvance, 116 Bunbury Road, Northfield, Birmingham, 31. In addition to the discussions on the proposed mammalogical society, there will be a programme of talks by leading British mammalogists. 